\title{
PENGARUH INDUKSI GAYA KOGNITIF REFLEKTIF TERHADAP PERSEPSI AKURASI BERITA PALSU (FAKE NEWS) PADA SITUASI EFEK KEBENARAN SEMU (ILLUSORY TRUTH EFFECT)
}

\author{
Muh. Zulfajri Shadiq Taswin dan Whisnu Yudiana \\ Fakultas Psikologi, Universitas Padjadjaran \\ E-mail: reyfajri164@gmail.com
}

\begin{abstract}
ABSTRAK. Penyebaran informasi yang begitu cepat ternyata kurang dapat diimbangi dengan jaminan bahwa informasi tersebut benar adanya. Fenomena beredarnya berita di dunia maya yang kontennya tidak sesuai dengan kenyataan, dikenal dengan istilah berita palsu (fake news). Semakin sering seseorang mendengar sebuah informasi, terlepas dari apakah informasi tersebut benar atau tidak, semakin mungkin pula ia mempercayai bahwa informasi tersebut benar. Fenomena tersebut dinamakan dengan efek kebenaran semu (illusory truth effect). Kecenderungan menggunakan salah satu dari dua proses kognitif yang ada, yakni proses tipe 1 (intuitif) atau tipe 2 (reflektif), ketika menerima berita palsu dinamakan gaya kognitif. Orang dengan gaya kognitif reflektif cenderung lebih mungkin untuk mampu membedakan berita palsu dari berita asli, dibandingkan orang dengan gaya kognitif intuitif. Penelitian ini bertujuan untuk mengetahui apakah dalam situasi efek kebenaran semu terjadi, seseorang yang diinduksikan gaya kognitif reflektif lebih mampu menilai berita palsu sebagai palsu dibandingkan orang yang tidak terinduksi. Penelitian ini menggunakan pendekatan eksperimen dengan metode between participant post-test only design yang dilakukan pada 215 mahasiswa Fakultas Psikologi Universitas Padjadjaran menggunakan simple random sampling. Induksi gaya kognitif reflektif diberikan pada kelompok eksperimen menggunakan metode Visual Priming gambar patung The Thinker. Data hasil penelitian dianalisis menggunakan uji statistik Mann-Whitney U dua sampel bebas. Hasil penelitian ini menunjukkan bahwa tidak terdapat pengaruh induksi gaya kognitif reflektif terhadap persepsi akurasi berita palsu dalam situasi adanya efek kebenaran semu. Penjelasan dominan yang menjadi dugaan peneliti ialah karena induksi menggunakan visual priming gambar patung The Thinker tidak dapat direplikasi pada penelitian ini.
\end{abstract}

Kata kunci: Berita Palsu, Induksi Gaya Kognitif Reflektif, Efek Kebenaran Semu, Visual Priming

\section{EFFECT OF THE INDUCTION OF REFLECTIVE COGNITIVE STYLE ON PERCEIVED ACCURACY OF FAKE NEWS UNDER THE INFLUENCE OF ILLUSORY TRUTH EFFECT}

\begin{abstract}
The tendency to use one of two cognitive processes; type 1 (reflective) and type 2 (intuitive) when receiving fake news is called cognitive style. People with reflective cognitive style are more likely able to accurately perceive fake news as fake, compared to people with intuitive cognitive style. Illusory truth effect refers to increased perception of truth as a consequence of familiarity. The present study aimed to find out whether in situations where illusory truth effect is induced, people who were induced to use a more reflective cognitive style could more accurately perceive fake news as fake, compared to people who were not induced. This study used an experimental approach with the between participant post-test only design method, to 215 college students from the Faculty of Psychology, Universitas Padjadjaran through simple random sampling. Data was analyzed using the Mann-Whitney U independent samples statistic test. The result of this study showed that there was no significant effect of induction of reflective cognitive style towards fake news accuracy under the illusory truth effect. The dominant explanation regarding this finding is that the method of induction, which used a visual priming of Auguste Rodin's The Thinker could not be replicated in this study.
\end{abstract}

Key words: Fake News, Cognitive Style, Induction, Illusory Truth Effect, Visual Priming

\section{PENDAHULUAN}

Perkembangan teknologi yang begitu cepat mendatangkan era baru pada kehidupan manusia, yakni era di mana informasi yang beredar begitu cepat dan mudah didapatkan. Meskipun begitu, penyebaran informasi yang begitu cepat ternyata kurang dapat diimbangi dengan jaminan bahwa berita-berita yang diperoleh merupakan berita yang akurat dan benar (Lazer et al., 2017). Hal tersebut diafirmasi dengan munculnya fenomena yakni beredarnya informasi dalam bentuk berita-berita di dunia maya yang kontennya tidak sesuai dengan kenyataan. Berita-berita tersebut, yang menimbulkan dampak negatif pada masyarakat dari taraf individual hingga taraf negara, kemudian dikenal dengan istilah berita palsu (fake news) (Allcott \& Gentzkow, 2017; Lilleker, 2017). Berita palsu didefinisikan sebagai "penyebaran informasi keliru secara sengaja, baik melalui media tradisional ataupun melalui media sosial" (Lilleker, 2017). Pada era di mana informasi beredar begitu cepat ini, berita yang diterima seseorang pun bisa merupakan berita asli yang benar adanya, atau berita palsu yang tidak benar adanya.

Berita palsu memiliki dampak pada konteks lokal maupun global, di antaranya digunakan sebagai senjata politik (Fielding-Smith, 2017; Khaldarova \& Pantti, 2016; Goldman, 2016) termasuk kampanye presidensial (Silverman, Strapagiel, Shaban, \& Hall, 2016), menimbulkan persepsi keliru mengenai fenomena alam (Gupta, Lamba, Kumaraguru, \& Joshi, 2013), persekusi (Azali, 2017), hingga persepsi keliru mengenai kandungan dalam mak-anan tertentu (Goh, 2017).

Penjelasan mengenai proses bagaimana seseorang dapat tertipu berita palsu cukup beragam, di antaranya 
penggunaan heuristik dalam menentukan kebenaran suatu informasi (Swire, Berinsky, Lewandowsky, \& Ecker, 2017). Hal tersebut dapat menyebabkan kecenderungan menerima informasi baru secara langsung tanpa diproses dengan kritis (Lazer et al., 2017) atau bahkan mendorong seseorang menggunakan evaluasi rasionalnya untuk membenarkan informasi tersebut sesuai dengan kepercayaan sebelumnya (Kahan, 2013). Heuristik lain yang dapat digunakan ialah bagaimana familiaritas terhadap informasi memengaruhi persepsi terhadap kebenaran dari berita tersebut; semakin sering seseorang mendengar sebuah informasi, terlepas dari apakah informasi tersebut benar atau tidak, semakin mungkin pula ia mempercayai bahwa cerita tersebut benar. Fenomena tersebut dinamakan dengan efek kebenaran semu (illusory truth effect) (Pennycook, Cannon, \& Rand, 2017). Familiaritas, dalam hal ini persepsi "pernah melihat informasi ini sebelumnya", meningkatkan kemudahan dalam memproses informasi yang nantinya digunakan sebagai heuristik untuk menilai akurasi dari informasi tersebut (Alter \& Oppenheimer, 2009). Efek kebenaran semu ini telah terbukti mampu membuat seseorang lebih mempercayai kebenaran dari berita palsu, karena berita tersebut dipersepsikan sebagai berita yang lebih familiar, atau "tidak asing di telinga" (Pennycook et al., 2017).

Ketika menerima berita palsu, manusia menggunakan salah satu dari dua proses kognitif yang digunakannya ketika menalar atau mengambil keputusan, yakni proses kognitif tipe 1 dan tipe 2 (Evans, 2008a; Evans \& Stanovich, 2013). Proses tipe 1 merupakan proses yang intuitif, cepat, otonom, berkapasitas tinggi dan tidak memerlukan kapasitas working memory, sedangkan proses tipe 2 merupakan proses yang reflektif, lambat, dan membutuhkan sumber daya yang banyak termasuk di dalamnya kapasitas working memory. Kecenderungan menggunakan salah satu dari dua proses tersebut dinamakan dengan gaya kognitif, yakni gaya kognitif intuitif dan reflektif(Pennycook, 2016). Orang yang memiliki gaya kognitif intuitif akan cenderung menggunakan proses tipe 1 saat menerima berita palsu, sehingga tidak memproses berita tersebut dengan hati-hati dan lebih mungkin untuk menggunakan heuristik, dan kurang akurat dalam menilai berita palsu (Pennycook et al., 2017). Sebaliknya, orang yang memiliki gaya kognitif reflektif akan cenderung menggunakan proses tipe 2, sehingga lebih mungkin untuk memproses berita dengan lebih lama dan hati-hati, dan dapat menilai berita palsu dengan lebih akurat (Pennycook \& Rand, 2017). Indikator yang sering digunakan untuk menunjukkan seseorang memiliki gaya kognitif reflektif ataupun intuitif ialah skor pada Cognitive Reflection Test (CRT) (Frederick, 2005; Pennycook \& Rand, 2017). Dikarenakan salah satu ciri dari penggunaan proses kognitif tipe 2 ialah lebih lambat daripada tipe 1, waktu reaksi yang lebih lama dalam kondisi eksperimental juga dipersepsikan sebagai indikator dari penggunaan proses tipe 2 (Pennycook, 2016; Thompson, Prowse Turner, \& Pennycook, 2011). Meskipun gaya kognitif merupakan perbedaan individual, gaya kognitif tersebut dapat dirubah melalui proses induksi dengan gaya kognitif tertentu (Pennycook, Fugelsang, \& Koehler, 2015; Shenhav, Rand, \& Greene, 2012; Gervais \& Norenzayan, 2012).

Beberapa penelitian mengenai metode induksi yang dapat mengubah gaya kognitif telah banyak dilakukan (Shenhav et al., 2012; Rand, Greene, \& Nowak, 2012; Uhlmann et al., 2011; Paxton, Ungar, \& Greene, 2011; Alter et al., 2007; Song \& Schwarz, 2008). Lebih lanjut, Gervais \& Norenzayan (2012) mencoba membandingkan efektivitas dari beberapa metode, di antaranya prosedur priming menggunakan tugas verbal fluency (Uhlmann et al., 2011), penggunaan jenis font (gaya penulisan) yang lebih sulit untuk dibaca (Alter et al., 2007; Song \& Schwarz, 2008), pemaparan terhadap alat ukur CRT (Paxton, Ungar, \& Greene, 2011), serta metode visual priming yakni pemampangan empat gambar patung The Thinker karya Auguste Rodin selama 30 detik untuk setiap gambarnya. Hasilnya ialah metode visual priming mampu meningkatkan kecenderungan seseorang berpikir reflektif dengan effect size yang paling besar. Visual priming merupakan metode priming di mana subjek ditunjukkan sebuah stimulus awal (prime) dan kemudian diminta untuk membuat sebuah keputusan (contohnya, menamakan sebuah stimulus) atau menghasilkan respon (contohnya, menyebutkan sebuah kata) pada stimulus berikutnya (test). Efek priming yang dihasilkan berupa orang tersebut lebih cenderung untuk berpikir dan berkontemplasi, dikarenakan sebelumnya sudah dipampangkan patung yang memiliki pose sedang berpikir dan berkontemplasi (Gervais \& Norenzayan, 2012).

Penelitian sebelumnya oleh Pennycook dan kawan-kawan (2017) mengenai pengaruh efek kebenaran semu terhadap persepsi akurasi dari berita palsu, serta penelitian Pennycook \& Rand (2017) yang menunjukkan kecenderungan orang dengan gaya kognitif intuitif untuk rentan mempercayai berita palsu, telah menerangkan pada kita bagaimana mekanisme orangorang untuk dapat keliru dalam menilai akurasi dari berita palsu. Akan tet-api, sejauh ini penelitian yang dillakukan masih bersifat korelasional (Pennycook \& Rand, 2017) dan bukan merupakan penelitian bersifat kausalitas atau eksperimental. Pemberian induksi untuk memunculkan gaya kognitif reflektif dapat dilihat pengaruhnya pada variabel persepsi akurasi berita palsu dalam kondisi eksperimental, sehingga dapat menjadi bukti apakah benar terdapat hubungan kausalitas, bukan hanya korelasional, antara gaya kognitif dan persepsi akurasi berita palsu. Selain itu, peneliti ingin melihat juga apakah dalam kondisi di mana efek kebenaran semu terjadi, seseorang yang memiliki gaya kognitif reflektif tetap mampu untuk menilai kebenaran berita dengan akurat. Hal ini dikarenakan efek kebenaran semu merupakan refleksi dari kenyataan yang terjadi, yakni adanya pengulangan-pengulangan informasi oleh media massa maupun media sosial. 
Pertanyaan penelitian yang ingin dijawab melaluai penelitian ini adalah apakah dalam kondisi efek kebenaran semu, orang yang terinduksi untuk menggunakan gaya kognitif reflektif dapat lebih mampu menilai kebenaran dari berita palsu dengan lebih akurat, daripada orang yang tidak terinduksi? Hasil dari penelitian ini dapat pula menjadi dasar intervensi yang dapat dilakukan pada masyarakat luas, agar orang yang tidak memiliki gaya kognitif reflektif pun mampu diinduksi untuk menjadi lebih reflektif sehingga dapat menilai berita palsu sebagai palsu.

\section{METODE}

Metode. Rancangan penelitian ini adalah between participant posttest-only design di mana responden ditugaskan ke dalam dua kelompok, yakni kelompok eksperimen dan kelompok kontrol. Variabel bebas (induksi gaya kognitif reflektif) diinduksikan pada kelompok eksperimen, namun tidak diinduksikan pada kelompok kontrol. Variabel terikat (persepsi akurasi berita palsu) kemudian diadministrasikan ke dalam kedua kelompok, kelompok eksperimen dan kontrol, sebagai bentuk posttest dalam desain penelitian ini. Perbedaan antara skor post-test dari kelompok eksperimen dan kelompok kontrol diuji secara statistik untuk mengukur pengaruh variabel bebas (Christensen, 2004).

Partisipan. Sebanyak 215 mahasiswa dari Fakultas Psikologi Universitas Padjadjaran di Bandung mengikuti penelitian ini. Partisipan dibagi menjadi dua kelompok yakni 107 responden untuk kelompok eksperimen dan 108 responden untuk kelompok kontrol. Rentang usia partisipan ialah dari usia 17-22 tahun $(\mathrm{M}=19.50, \mathrm{SD}=$ 1.072). Secara keseluruhan jumlah responden perempuan $(\mathrm{n}=180)$ lebih banyak dibandingkan dengan responden laki-laki $(\mathrm{n}=35)$.

Alat Ukur. Terdapat dua alat ukur yang digunakan pada penelitian in. Pertama, alat ukur Cognitive Reflection Test (CRT), yang digunakan dalam rangka matching partisipan, serta alat ukur Persepsi Akurasi Berita Palsu, yang digunakan dalam rangka mengetahui persepsi akurasi partisipan terhadap berita-berita tertentu. Alat ukur CRT diadaptasi dari alat ukur CRT versi asli (Frederick, 2005), dan versi revisi (Thomson \& Oppenheimer, 2016). Jumlah keseluruhan butir alat ukur yang telah diadaptasi sebanyak 6 butir. Setelah di ujicobakan pada 215 mahasiswa Fakultas Psikologi Universitas Padjadjaran, didapatkan nilai reliabilitas akhir .788, yakni masuk dalam kategori 'dapat diandalkan' berdasarkan kriteria Kaplan dan Sacuzzo (2005).

Kedua, alat ukur Persepsi Akurasi Berita Palsu dibuat dengan mengacu pada kuesioner penilaian akurasi berita palsu pada penelitian Pennycook dan kawan-kawan (2017). Kuesioner tersebut berupa pemaparan judul-judul berita yang dibuat menyerupai judul berita di Facebook, yang mana terdapat 24 berita secara keseluruhan (12 berita palsu dan 12 berita asli). Berita ditampilkan hanya berbentuk judul saja, karena masyarakat biasanya membaca ber- ita di media sosial dengan membaca judul beritanya saja (Gabielkov et al., 2016). Setelah berita dipaparkan, partisipan diminta untuk menjawab dua butir pertanyaaan yakni:

a. Pertanyaan untuk mengetahui penilaian akurasi mengenai berita. Pertanyaan yang ditanyakan ialah, "Menurut Anda, seberapa benarkah pernyataan pada judul berita tersebut?" Pilihan jawabannya antara lain 1) Sangat tidak benar, 2) Kurang benar, 3) Cukup benar, 4) Sangat benar.

b. Pertanyaan untuk mengetahui persepsi partisipan mengenai familiaritas terhadap berita. Hal ini dilakukan untuk memeriksa apakah manipulasi untuk menimbulkan efek berita palsu (yakni pemaparan 6 berita palsu dan 6 berita asli pada fase familiaritas) berhasil atau tidak (manipulation check). Pertanyaan yang ditanyakan ialah "Menurut Anda, seberapa familiarkah berita di atas bagi Anda?" Pilihan jawabannya antara lain 1) Sama sekali tidak pernah mendengar berita tersebut sebelumnya, 2) Pernah mendengar berita tersebut sebelumnya, 3) Sering mendengar berita tersebut sebelumnya, 4) Sangat sering mendengar berita tersebut sebelumnya.

Alat Ukur Persepsi Akurasi Berita Palsu telah diujicobakan pada 215 mahasiswa Fakultas Psikologi Universitas Padjadjaran. Hasil uji reliabilitas menunjukkan bah-wa alat ukur dengan total 24 butir memiliki reliabilitas yang dapat diandalkan berdasarkan kriteria Kaplan dan Sacuzzo (2005), ditunjukkan dengan $\alpha=.81$.

Validitas alat ukur telah dipastikan oleh sumber diperolehnya berita palsu. Berita palsu dibuat dengan cara mengumpulkan berita-berita palsu yang telah dibuktikan kepalsuannya oleh situs-situs yang mengungkap hoax dan berita palsu (fact-checker), baik situs internasional yakni Snopes.com (Pennycook et al., 2017; Pennycook \& Rand, 2017) dan situs nasional yakni turnbackhoax.id (Budiman, 2017). Berita-berita palsu tersebut kemudian dibuat menyerupai judul berita di Facebook, mengikuti desain berita palsu pada penelitian Pennycook dan kawan-kawan (2017) dan Pennycook dan Rand (2017).

Skor partisipan pada alat ukur persepsi akurasi berita palsu ini didapatkan dengan cara menghitung rata-rata dari jawaban terhadap pertanyaan mengenai persepsi akurasi partisipan terhadap berita palsu, dalam rentang skor 1 hingga 4 untuk setiap berita palsu yang dipaparkan. Dalam hal ini, terdapat total 12 berita palsu yang dipaparkan, 6 di antaranya dipaparkan di awal sebagai bentuk manipulasi untuk menciptakan adanya efek kebenaran semu. Alat ukur dipaparkan kepada partisipan dalam bentuk tampilan pada software yaitu OpenSesame versi 3.2.4 Kafkaesque Koffka. OpenSesame adalah sebuah software yang didesain khusus untuk melakukan penelitian eksperimental dalam bidang psikologi, neuroscience dan ekonomi eksperimental (Mathot, Schreij \& Theeuwes, 2012).

Prosedur. Pada penelitian ini, responden dibagi menjadi 2 kelompok, yaitu kelompok eksperimen dan kelompok kontrol. Partisipan ditempatkan ke dalam salah 
satu diantara kedua kelompok tersebut secara acak (random assignment) dan terlebih dahulu dilakukan matching by frequency distribution control untuk mengontrol pengaruh perbedaan gaya kognitif pada kedua kelompok, karena perbedaan gaya kognitif berpotensi menjadi variabel ekstraneous (Christensen, 2004). Matching dilakukan dengan cara membagi kelompok berdasarkan skor pada alat ukur Cognitive Reflection Test (CRT), yakni alat ukur untuk mengetahui gaya kognitif seseorang. Semakin tinggi skor pada CRT, semakin reflektif seseorang, dan sebaliknya. Matching dilakukan dengan cara membagi kelompok berdasarkan skor pada alat ukur CRT, sehingga didapatkan rata-rata skor CRT kedua kelompok sama.

Dikarenakan penelitian ini mengenai berita palsu, maka partisipan tidak boleh mengetahui bahwa berita-berita yang dipaparkan sebagian merupakan berita palsu. Hal tersebut berpotensi menjadikan partisipan lebih waspada akan berita palsu, sehingga dapat menyebabkan hasilnya menjadi bias. Untuk menghindari hal tersebut, peneliti menggunakan teknik deception, yakni teknik dalam penelitian yang dilakukan untuk membuat partisipan tidak mengetahui tujuan sebenarnya dari penelitian yang dilakukan; lebih spesifiknya, peneliti menggunakan jenis active deception, yaitu secara sengaja memberikan informasi yang keliru kepada partisipan (Christensen, 2004). Teknik deception dilakukan dengan cara memberitahu pada partisipan di awal penelitian, bahwa tujuan dari penelitian ini ialah untuk melihat "pengaruh tampilan berita terhadap persepsi akurasi berita palsu". Partisipan lalu diberitahukan mengenai tujuan asli dari penelitian ini sebagai bentuk debriefing di akhir penelitian.

Terdapat tiga tahap dalam penelitian ini yakni tahap familiaritas, distractor, dan asesmen, mengacu pada penelitian sebelumnya oleh Pennycook dan kawan-kawan (2017). Pada tahap familiaritas, partisipan pertama-tama dipaparkan serangkaian judul (headline) berita yang berisi 6 berita palsu dan 6 berita asli; hal ini untuk memberikan 'efek kebenaran semu' yang mana keterpaparan satu kali terhadap sebuah berita saja dapat meningkatkan kepercayaan terhadap berita tersebut (Pennycook et al., 2017). Partisipan juga diminta untuk menilai pada setiap judul berita, dari skala 1-4, seberapa familiar atau akrabkah partisipan dengan judul berita yang telah dipaparkan. Hal ini dilakukan untuk mengetahui apakah partisipan sudah pernah terpapar informasi pada judul-judul berita tersebut sebelumnya. Kemudian, sesuai dengan metode pada penelitian Pennycook dan kawan-kawan (2017), pada tahap distractor partisipan diberi serangkaian pertanyaan demografis. Istilah "distractor" di sini, berdasarkan penelitian sebelumnya oleh Pennycook dan kawan-kawan (2017), diartikan sebagai pengalih, yakni untuk mengalihkan atensi partisipan dari berita-berita yang telah dipampangkan pada tahap familiaritas. Prosedur pada tahap familiaritas dan distractor ini dilakukan untuk memunculkan efek kebenaran semu pada partisipan. Prosedur ini telah diuji sebelumnya melalui studi awal yang dilakukan peneliti pada mahasiswa Fakultas Psikologi Universitas Padjadjaran.

Sebelum memasuki tahap terakhir yakni tahap asesmen, partisipan pada kelompok eksperimen lalu diberikan induksi gaya kognitif reflektif, untuk menstimulasi pemikiran reflektif yang mengakibatkan kecenderungan menggunakan proses kognitif tipe 2 (Gervais \& Norenzayan, 2012). Metode induksi yang digunakan pada penelitian ini ialah metode induksi yang digunakan pada penelitian Gervais \& Norenzayan (2012), di mana partisipan diminta untuk melihat dengan seksama empat gambar patung The Thinker karya Auguste Rodin. Keempat gambar tersebut menampilkan objek yang sama, meskipun dalam posisi, warna, dan ukuran yang berbeda-beda, dan terpampang secara berurutan, satu demi satu selama 30 detik.

Pada tahap terakhir yakni tahap asesmen, pengukuran kemampuan membedakan berita palsu dari yang asli dilakukan dengan menggunakan kuesioner penilaian berita palsu pada studi Pennycook dan kawan-kawan (2017), di mana sebanyak 24 berita di antaranya 12 berita palsu (6 berita palsu yang sudah dipaparkan sebelumnya pada partisipan dan 6 berita palsu yang belum pernah dipaparkan) serta 12 berita asli ( 6 berita asli yang sebelumnya sudah dipaparkan pada partisipan dan 6 berita asli yang belum pernah dipaparkan sebelumnya) dipaparkan satu demi satu pada partisipan lalu diberikan skala penilaian berbentuk likert agar partisipan dapat memberikan penilaian mengenai akurasi dari setiap berita palsu yang dipaparkan. Partisipan juga diberikan pertanyaan 'seberapa akrabkah (familiar) berita ini bagi Anda?’ di setiap b-erita sebagai bentuk pengecekan terhadap manipulasi yang diberikan pertama kali, yakni pemaparan 6 berita palsu untuk menimbulkan efek kebenaran semu (Pennycook et al., 2017). Partisipan diukur waktu reaksi yakni waktu yang dibutuhkan sejak pertama kali berita dipaparkan dan ketika memberi penilaian akurasi dari berita tersebut. Hal ini dilakukan untuk melihat apakah partisipan menggunakan gaya kognitif reflektif atau tidak setelah diberikan induksi, dikarenakan waktu reaksi yang lama merupakan salah satu ciri seseorang sedang menggunakan pemikiran analitis dan reflektif (Pennycook, 2016). Pada tahap terakhir ini pula partisipan diberikan dua pertanyaan untuk melihat apakah terdapat pengaruh induksi gaya kognitif reflektif menggunakan visual priming pada diri partisipan menurut partisipan sendiri. Data yang didapatkan berupa data self-report, dan kedua pertanyaan yang ditanyakan merupakan pertanyaan terbuka. Jawaban partisipan akan dianalisis menggunakan kategorisasi. Dapat dilihat pada Gambar 1.

Uji Statistik. Uji statistik untuk mengetahui perbedaan dua sampel bebas dilakukan untuk mengetahui pengaruh induksi gaya kognitif reflektif terhadap persepsi akurasi berita palsu, serta untuk mengetahui pengaruh efek kebenaran semu terhadap persepsi akurasi berita. Karena data merupakan data ordinal, uji nonparametrik Mann-Whitney U digunakan pada penelitian ini. Meskipun begitu, uji parametrik t-test akan dipakai untuk data waktu reaksi, karena data waktu reaksi merupakan data rasio. Uji 


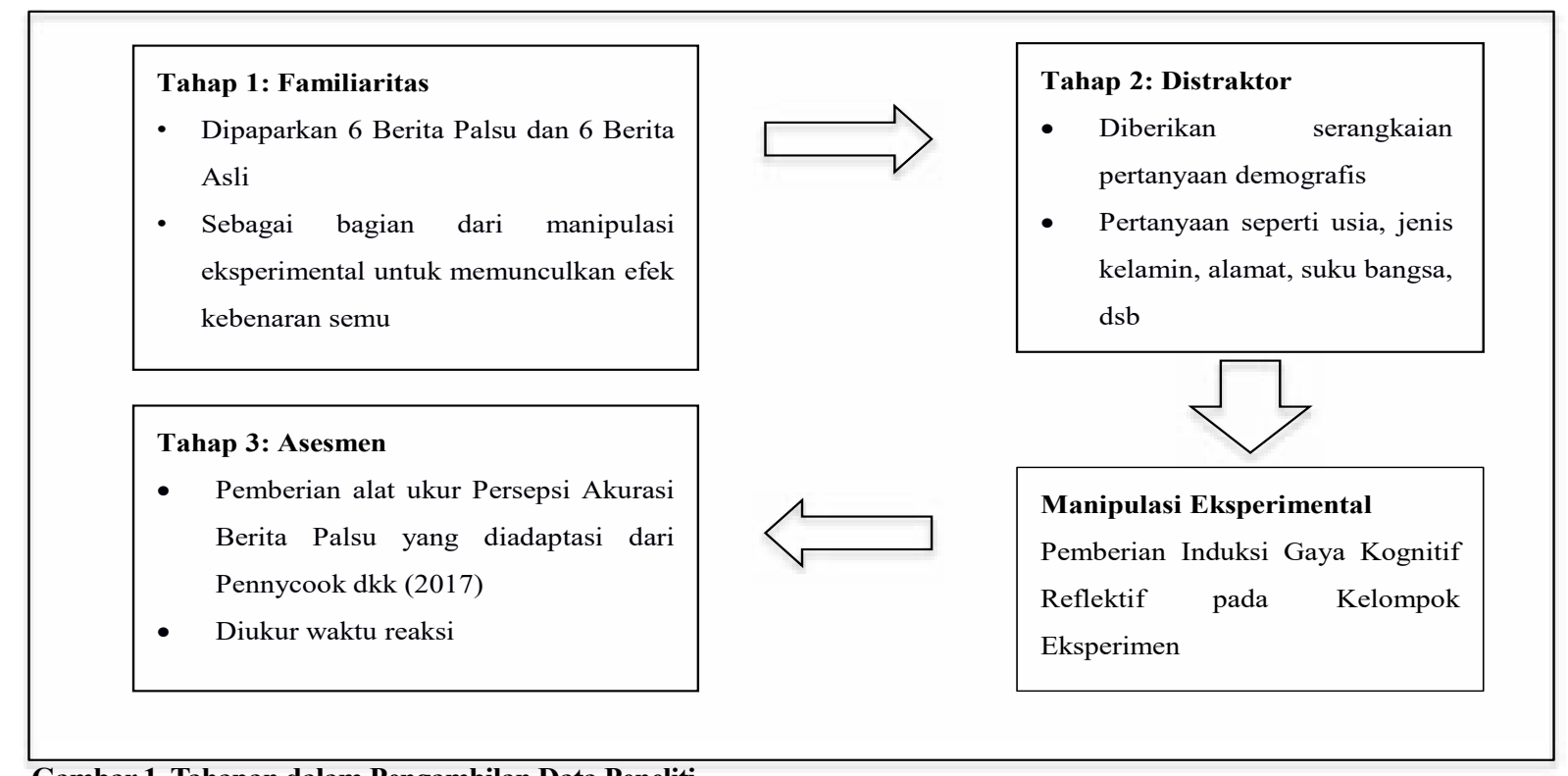

Gambar 1. Tahapan dalam Pengambilan Data Peneliti

t-test dua sampel bebas dilakukan jika data telah terbukti berdistribusi normal dan memiliki homogenitas varians.

\section{HASIL DAN PEMBAHASAN}

Hasil uji Mann-Whitney U dua sampel bebas antara lain, data skor persepsi akurasi berita palsu kelompok eksperimen $(\mathrm{N}=107, \mathrm{Mdn}=2.33)$ dan kelompok kontrol $(\mathrm{N}=108, \mathrm{Mdn}=2.33)$ tidak berbeda secara signifikan, dengan $U=5378.000, p=.379, r=-.06$ (dapat dilihat pada tabel 1). Hasil ini menunjukkan bahwa tidak terdapat pengaruh signifikan dari induksi gaya kognitif reflektif terhadap persepsi akurasi berita palsu dalam situasi adanya efek kebenaran semu.

Tabel 1. Hasil uji Mann Whitney U persepsi akurasi berita palsu kelompok kontrol dan eksperimen dalam situasi adanya efek kebenaran semu

\begin{tabular}{cccccc}
\hline $\begin{array}{c}\text { Persepsi Akurasi } \\
\text { Berita Palsu }\end{array}$ & N & Median & $\boldsymbol{U}$ & $\boldsymbol{P}$ & $\boldsymbol{r}$ \\
\hline Kelompok Kontrol & 108 & 2.33 & & & \\
KelompokEksperimen & 107 & 2.33 & 5378.000 & .379 & -.06 \\
\hline
\end{tabular}

Keterangan: $\mathrm{r}=$ effect size untuk uji Mann-Whitney U.

Peneliti juga menghitung waktu reaksi partisipan penelitian ketika menjawab pertanyaan mengenai persepsi akurasi berita palsu di tahap asesmen. Ini berdasarkan pada penemuan sebelumnya bahwa waktu reaksi yang lama merupakan salah satu ciri seseorang sedang menggunakan pemikiran analitis dan reflektif(Pennycook, 2016). Keseluruhan waktu reaksi untuk setiap butir berita kemudian dirata-ratakan, sehingga terdapat data rata-rata waktu reaksi untuk setiap partisipan. Peneliti kemudian melihat perbedaan waktu reaksi antara kelompok eksperimen dan kontrol.

Hasil uji normalitas menunjukkan bahwa data waktu reaksi kedua kelompok tidak berdistribusi normal (eksperimen: $\mathrm{M}=5503.1279, \mathrm{SD}=1517.48281, \mathrm{p}=.096$; kontrol $\mathrm{M}=5277.1157, \mathrm{SD}=1607.72226, \mathrm{p}<.001)$ dan memiliki varians yang homogen $(\mathrm{L}(1,213)=.003, \mathrm{p}=$ $0.958)$. Hasil pengujian Mann-Whitney U dua sampel berpasangan dapat dilihat pada tabel 2 .

Tabel 2. Hasil uji Mann Whitney U waktu reaksi kelompok kontrol dan eksperimen

\begin{tabular}{lccccc}
\hline & $N$ & Median & $\boldsymbol{U}$ & $\boldsymbol{P}$ & $\boldsymbol{r}$ \\
\hline $\begin{array}{l}\text { Waktu Reaksi } \\
\text { Kelompok }\end{array}$ & 108 & 5015.2292 & & & \\
Kontrol & & & 5141.000 & .163 & -.10 \\
$\begin{array}{l}\text { Waktu Reaksi } \\
\text { Kelompok }\end{array}$ & 107 & 5249.4167 & & & \\
$\begin{array}{l}\text { Eksperimen } \\
\text { Keterangan: } \mathrm{r}=\text { effect size untuk uji Mann-Whitney U. }\end{array}$
\end{tabular}

Hasil pengujian Mann-Whitney U menunjukkan bahwa rata-rata waktu reaksi pada kelompok eksperimen $(\mathrm{N}=107, \mathrm{Mdn}=5249.4167)$ tidak berbeda secara signifikan dengan rata-rata waktu reaksi pada kelompok kontrol $(\mathrm{N}=108, \mathrm{Mdn}=5015.2292)$, dengan $\mathrm{U}=5141.000, \mathrm{p}$ $=.163, \mathrm{r}=-.10$. Hasil tersebut menunjukkan bahwa tidak terdapat perbedaan signifikan antara rata-rata waktu reaksi pada kelompok kontrol maupun kelompok eksperimen.

Partisipan ditanyakan dua pertanyaan di akhir penelitian untuk mengetahui pengaruh induksi visual priming yang berbentuk self-report. Seluruh partisipan pada kelompok eksperimen diberi pertanyaan tersebut, namun dikarenakan kesalahan teknis, jawaban partisipan pada hari pertama tidak dapat dikomputasikan. Total partisipan yang dapat dikomputasikan jawabannya sebanyak 60 partisipan. Jawaban partisipan kemudian dikategorisasikan sehingga terdiri dari beberapa kelompok jawaban yang berbeda, seperti yang dapat dilihat pada gambar 2 .

Pertanyaan pertama yakni mengenai apa yang dirasakan ketika melihat gambar patung, jawaban responden yang menunjukkan bahwa responden lebih reflektif (lebih terdorong untuk berpikir) hanyalah $14.52 \%$ dari seluruh jawaban, yakni jawaban yang mengandung kalimat seperti "mengenali patung yang sedang berpikir" dan "ikut berpikir". Jawaban lainnya 


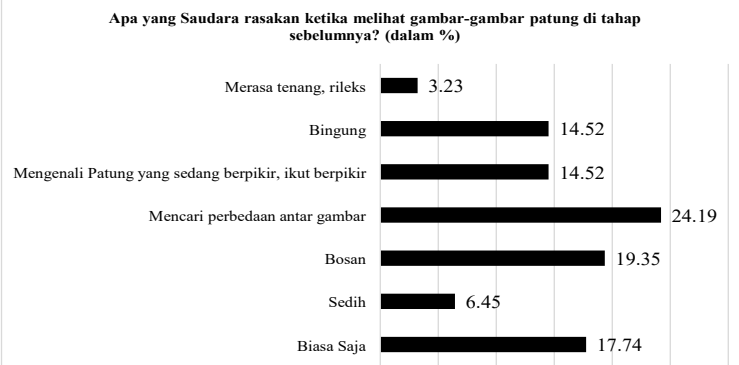

Gambar 2. Persentase jawaban partisipan mengenai apa saja yang dirasakan ketika melihat gambar patung The Thinker

tidak menunjukkan kecenderungan untuk berpikir lebih reflektif. Hasil tersebut menunjukkan bahwa hanya sebagian kecil (14.52\%) dari 60 partisipan kelompok eksperimen yang menunjukkan indikasi lebih reflektif ketika melihat gambar The Thinker.

Pertanyaan kedua yakni mengenai perubahan yang dirasakan setelah melihat gambar patung The Thinker, jawaban responden yang menunjukkan keadaan yang lebih reflektif dibanding sebelumnya ialah sebanyak 18.64\% atau jawaban terbanyak kedua. Seperti yang dapat dilihat pada gambar 3, jawaban paling banyak ialah "tidak ada pengaruh apapun yang dirasakan" yakni sebanyak $59.32 \%$. Dikarenakan jawaban yang menunjukkan adanya perubahan menjadi lebih reflektif hanya sebanyak $18,64 \%$, sedangkan lebih dari setengah responden menjawab 'tidak ada efek yang dirasakan', maka peneliti menyimpulkan bahwa visual priming dengan menunjukkan gambar The Thinker tidak terindikasi mampu menghasilkan efek yang diinginkan.

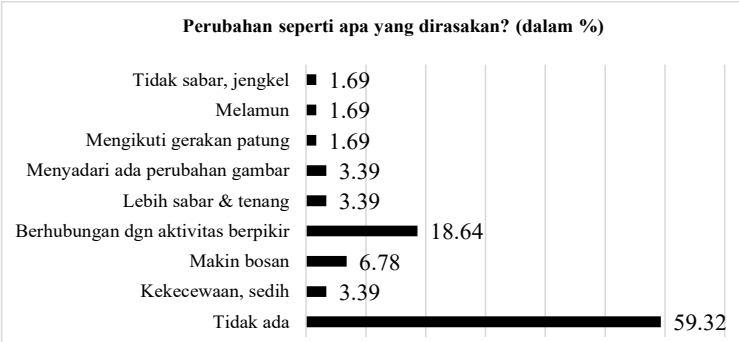

Gambar 3. Persentase jawaban partisipan mengenai perubahan apa saja yang dirasakan setelah melihat gambar patung The Thinker

Hasil penelitian tidak sesuai dengan hipotesis awal, yaitu induksi gaya kognitif reflektif berpengaruh terhadap persepsi akurasi berita palsu dalam situasi adanya efek kebenaran semu. Dengan kata lain, induksi gaya kognitif reflektif tidak mampu membuat partisipan mempersepsikan berita palsu sebagai palsu ketika dipengaruhi oleh efek kebenaran semu, sehingga akan membuat skor persepsi akurasi berita palsu lebih rendah secara signifikan pada kelompok eksperimen dibandingkan dengan kelompok kontrol. Hasil ini juga tidak sesuai dengan hasil pada penelitian sebelumnya oleh Pennycook dan Rand (2017), di mana terdapat indikasi bahwa orang-orang yang memiliki gaya kognitif reflektif lebih cenderung untuk mampu mempersepsikan berita palsu sebagai palsu meskipun berita palsu tersebut familiar.
Penjelasan mengenai mengapa secara konseptual metode induksi visual priming dengan menggunakan The Thinker tidak dapat direplikasi pada penelitian ini, diduga disebabkan kemungkinan bahwa partisipan yang terinduksi tidak semuanya mengasosiasikan pose yang dimiliki patung The Thinker dengan aktivitas berpikir dan berkontemplasi. Hal ini bisa dilihat pada jawaban partisipan ketika ditanyakan mengenai apa yang dirasakan ketika melihat gambar The Thinker; hanya $14.52 \%$ partisipan yang bahkan mengenali bahwa patung tersebut sedang berpikir atau merasa terstimulasi untuk ikut berpikir. Justru, peneliti mendapati bahwa jawaban-jawaban partisipan cukup bervariasi, mulai dari merasa tenang dan rileks, merasa sedih dan kecewa, merasa bingung, tidak merasakan apa-apa, atau bahkan justru mencari-cari perbedaan dari setiap gambar. Dari jawaban-jawaban partisipan, peneliti menduga bahwa perbedaan persepsi masing-masing partisipan memiliki pengaruh terhadap asosiasi yang ditimbulkan mengenai The Thinker, sehingga ketika partisipan terpapar pada stimulus berikutnya (test), efek priming yang muncul adalah sesuai dengan apa yang diasosiasikan tersebut. Contohnya, ketika partisipan mengungkapkan bahwa ia semakin rileks dan tenang ketika melihat gambar patung, maka efek priming yang ditimbulkan ketika ia menilai akurasi dari berita ialah sesuai dengan asosiasi dengan gambar patung yang sudah ia lihat sebelumnya, yakni semakin rileks dan tenang. Oleh karena itu, peneliti menduga bahwa, efek priming yang diinginkan tidak dapat dihasilkan pada seluruh partisipan, dikarenakan subjektivitas setiap partisipan yang menyebabkan bervariasinya persepsi partisipan ketika melihat gambar patung The Thinker.

Hasil dari penelitian ini menunjukkan bagaimana induksi menggunakan visual priming tidak mampu memberikan hasil yang diharapkan pada populasi penelitian. Oleh karena itu, menurut peneliti penting untuk dilakukan studi lanjutan untuk melihat dan membandingkan efektivitas metode-metode induksi lain, yakni prosedur priming menggunakan tugas verbal fluency (Uhlmann et al., 2011) serta penggunaan jenis font (gaya penulisan) yang lebih sulit untuk dibaca (Alter et al., 2007; Song \& Schwarz, 2008), terhadap skor alat ukur gaya kognitif lain yang tersedia. Alat ukur gaya kognitif lain yang tersedia antara lain tugas silogisme (Gervais \& Norenzayan, 2012) serta alat ukur bias kepercayaan (belief bias) (Thomson \& Oppenheimer, 2016) di mana variabel gaya kognitif di kontrol untuk seluruh partisipan. Hasil dari penelitian tersebut akan menunjukkan induksi manakah yang memiliki efek terbesar, serta alat ukur manakah yang paling mampu untuk sensitif terhadap perubahan pada gaya kognitif partisipan.

Penelitian ini memiliki beberapa limitasi. Limitasi yang pertama ialah, tidak dilakukannya penelitian pendahuluan untuk mengetahui efektivitas induksi Gervais dan Norenzayan (2012) dalam meningkatkan pemikiran reflektif pada populasi sasaran. Penelitian pendahuluan tersebut berfungsi sebagai replikasi dari penelitian Gervais dan Norenzayan (2012) yang dilakukan secara komputer- 
isasi. Limitasi berikutnya ialah, keterbatasan pengukuran gaya kognitif sebagai bentuk matching hanya pada satu alat ukur saja, yakni CRT. Hal ini merupakan limitasi juga pada penelitian sebelumnya yang menggunakan CRT (penelitian Pennycook dan kawan-kawan (2017)), yakni terdapat kemungkinan alat ukur CRT secara murni tidak hanya mengukur gaya kognitif reflektif saja, namun juga dipengaruhi oleh variabel kemampuan untuk berpikir reflektif, seperti kemampuan berhitung dan kecerdasan. Limitasi terakhir ialah, terdapat kemungkinan bahwa setiap komputer memiliki waktu reaksi yang berbeda-beda ketika dioperasikan, dikarenakan spesifikasi yang berbeda-beda untuk setiap komputernya. Peneliti tidak dapat memastikan apakah waktu reaksi pada setiap komputer sudah sama atau tidak.

\section{SIMPULAN}

Dalam situasi adanya efek kebenaran semu, seseorang yang diinduksikan untuk berpikir reflektif lebih memiliki kecenderungan untuk tidak terpengaruh menggunakan heuristik sederhana seperti 'rasanya saya pernah melihat berita ini sebelumnya' yang meningkatkan kepercayaan terhadap berita tersebut. Oleh karena itu, seseorang yang diinduksikan untuk lebih berpikir reflektif ketika menerima berita palsu seharusnya lebih mampu untuk menilai dengan akurat, bahwa berita palsu adalah palsu dan berita asli adalah asli. Meskipun begitu, hasil penelitian ini tidak sesuai dengan hipotesis awal. Pada situasi efek kebenaran semu terjadi, orang yang diinduksikan untuk lebih berpikir reflektif tidak lebih baik dalam menilai kebenaran berita secara akurat, dibandingkan dengan orang yang tidak terinduksikan untuk berpikir reflektif. Penjelasan dominan hal ini dapat terjadi ialah, karena induksi untuk membuat seseorang lebih reflektif tidak mampu direplikasikan pada penelitian ini, disebabkan perbedaan persepsi ketika memaknakan gambar patung The Thinker karya Auguste Rodin. Pengembangan yang perlu dilakukan untuk memperbaiki penelitian ini adalah dilakukan studi lanjutan untuk melihat dan membandingkan efektivitas metode-metode induksi lain, terhadap skor alat ukur gaya kognitif lain yang tersedia. Selain itu, sebaiknya menentukan persyaratan minimal spesifikasi untuk setiap komputer yang dipakai dalam penelitian, agar waktu reaksi setiap komputer dapat dipastikan sama.

\section{DAFTAR PUSTAKA}

Allcott, H., \& Gentzkow, M. (2017). Social Media and Fake News in the 2016 Election. Journal of Economic Perspectives, 31(2), 211-236. https:// doi.org/10.1257/jep.31.2.211

Alter, A. L., \& Oppenheimer, D. M. (2009). Uniting the tribes of fluency to form a metacognitive nation. Personality and Social Psychology
Review, 13(3), 219-235. https://doi. org/10.1177/1088868309341564

Alter, A. L., Oppenheimer, D. M., Epley, N., \& Eyre, R. N. (2007). Overcoming intuition: metacognitive difficulty activates analytic reasoning. Journal of Experimental Psychology: General, 136(4), 569.

Azali, K. (2017). Singapore | 7 August 2017 Fake News and Increased Persecution in Indonesia, (61), 1-10.

Cave, C. B., Bost, P. R., \& Cobb, R. E. (1996). Effects of color and pattern on implicit and explicit picture memory. Journal of Experimental Psychology: Learning, Memory, and Cognition, 22(3), 639.

Christensen, L. B. (2004). Experimental methodology. Allyn \& Bacon.

Cochran, W. G. (1977). Sampling Techniques: $3 d$ Ed. New York: Wiley.

Cooper, L. A., Schacter, D. L., Ballesteros, S., \& Moore, C. (1992). Priming and recognition of transformed three-dimensional objects: Effects of size and reflection. Journal of Experimental Psychology: Learning, Memory, and Cognition, 18(1), 43.

Evans, J. S. B. T. (2008). Dual-Processing Accounts of Reasoning, Judgment, and Social Cognition. Annual Review of Psychology, 59(1), 255-278. https://doi. org/10.1146/annurev.psych.59.103006.093629

Evans, J. S. B. T., \& Stanovich, K. E. (2013). Dual-Process Theories ofHigherCognition:AdvancingtheDebate. Perspectives on Psychological Science, 8(3), 223241. https://doi.org/10.1177/1745691612460685

Frederick, S. (2005). Cognitive Reflection and Decision Making. Journal of Economic Perspectives, 19(4), 25-42. https:// doi. org/10.1257/089533005775196732

Gabielkov, M., Ramachandran, A., Chaintreau, A., Gabielkov, M., Ramachandran, A., Chaintreau, A., ... Chaintreau, A. (2016). Social Clicks: What and Who Gets Read on Twitter? To cite this version: Social Clicks : What and Who Gets Read on Twitter? SIGMETRICS Perform. Eval. Rev., 44(1), 179-192. https://doi.org/http://dx.doi. org/10.1145/2896377.290146ab

Goh, S. (2017). Fake news tells more than just lies, (March).

Grill-Spector, K. (2008). Visual priming.

Gupta, A., Lamba, H., Kumaraguru, P., \& Joshi, A. (2013). Faking Sandy: Characterizing and Identifying Fake Images on Twitter During Hurricane Sandy. Proceedings of the $22^{\text {nd }}$ International Conference on World Wide Web, 729-736. https://doi. org/10.1145/2487788.2488033 
Kahan, D. M. (2013). Working paper. Judgment and Decision Making, 8(4), 407-424. https://doi. org/10.2139/ssrn.2182588

Khaldarova, I., \& Pantti, M. (2016). Fake News: The narrative battle over the Ukrainian conflict. Journalism Practice, 10(7), 891-901. https://doi. org/10.1080/17512786.2016.1163237

Lazer, D., Baum, M., Grinberg, N., Friedland, L., Joseph, K., Hobbs, W., \& Mattsson, C. (2017). Combating Fake News: An Agenda for Research and Action, (May), 1-19.

Lenhart, A., Purcell, K., Smith, A., \& Zickuhr, K. (2010). Social Media \& Mobile Internet Use Among Teens and Young Adults. Audubon, 1(February).

Lilleker, D. G. (2017). Evidence to the Culture, Media and Sport Committee "Fake news" inquiry.

Mathôt, S., Schreij, D., \& Theeuwes, J. (2012). OpenSesame: An open-source, graphical experiment builder for the social sciences. Behavior Research Methods, 44(2), 314-324. doi:10.3758/s13428-011-0168-7

Paxton, J. M., Ungar, L., \& Greene, J. D. (2012). Reflection and reasoning in moral judgment. Cognitive Science, 36(1), 163-177.

Pennycook, G. (2016). What Makes us Think? A ThreeStage Dual-Process Model of Analytic Engagement. Waterloo, Ontario, Canada.

Pennycook, G., Cannon, T. D., \& Rand, D. G. (2017). Prior Exposure Increases Perceived Accuracy of Fake News. SSRNElectronic Journal, (December). https:// doi.org/10.2139/ssrn.2958246

Pennycook, G., Fugelsang, J. A., \& Koehler, D. J. (2015). EverydayConsequencesofAnalyticThinking.Current Directions in Psychological Science, 24(6), 425-432. https://doi.org/10.1177/0963721415604610

Pennycook, G., \& Rand, D. G. (2017). Who falls for fake news? The roles of analytic thinking, motivated reasoning, political ideology, and bullshit receptivity. Preprint, (September). https://doi.org/10.2139/ ssm.3023545

Rand, D. G., Greene, J. D., \& Nowak, M. A. (2012). Spontaneous giving and calculated greed. Nature, 489(7416), 427.
Sayres, R., \& Grill-Spector, K. (2008). Relating retinotopic and object-selective responses in human lateral occipital cortex. Journal of Neurophysiology, 100(1), 249-267.

Schwarz, N., J. Sanna, L., Skurnik, I., \& Yoon, C. (2007). Metacognitive Experiences and the Intricacies of Setting People Straight: Implications for Debiasing and Public Information Campaigns. Advances in Experimental Social Psychology, 39, 127-161.

Shenhav, A., Rand, D. G., \& Greene, J. D. (2012). Divine intuition: Cognitive style influences belief in God. Journal of Experimental Psychology: General, 141(3), 423-428. https://doi.org/10.1037/a0025391

Showkat, N., \& Parveen, H. (2017). Quadrant-I (e-Text). Diperoleh dari https://www.researchgate.net/ publication/319066480_NonProbability_and Probability_Sampling, diakses pada 6Agustus 2017.

Song, H., \& Schwarz, N. (2008). Fluency and the detection of misleading questions: Low processing fluency attenuates the Moses illusion. Social Cognition, 26(6), 791-799.

Swire, B., Berinsky, A. J., Lewandowsky, S., \& Ecker, U. K. H. (2017). Processing political misinformation: comprehending the Trump phenomenon. Royal Society Open Science, 4(3), 160802. https://doi. org/10.1098/rsos.160802

Thompson, V. A., Prowse Turner, J. A., \& Pennycook, G. (2011). Intuition, reason, and metacognition. Cognitive Psychology, 63(3), 107-140. https:/doi. org/10.1016/j.cogpsych.2011.06.001

Thomson, K. S., \& Oppenheimer, D. M. (2016). Investigating an alternate form of the cognitive reflection test. Judgment and Decision Making, 11(1), 99-113. https://doi.org/ISBN 978-615-5270-17-8

Uhlmann, E. L., Poehlman, T. A., Tannenbaum, D., \& Bargh, J.A. (2011). Implicit Puritanism in American moral cognition. Journal of Experimental Social Psychology, 47(2), 312-320.

Unkelbach, C. (2007). Reversing the truth effect: Learning the interpretation of processing fluency in judgments of truth. Journal of Experimental Psychology: Learning Memory and Cognition, 33(1), 219-230. https://doi.org/10.1037/0278-7393.33.1.219200 